\title{
Retrofitting the Existing Requirements and the Associated Existing Services for an Institutional Building to Enhance the Functionality of the Built Environment
}

\author{
Kuldeep Kumar \\ Masters in Building Engineering and Management \\ School of Planning and Architecture, \\ New Delhi
}

\author{
Devika Nayal \\ Masters in Building Engineering and Management \\ School of Planning and Architecture, \\ New Delhi
}

\begin{abstract}
Retrofitting an existing building can oftentimes be more economical than building a new facility. The existing buildings comprise the largest segment of the built environment, it is important to initiate retrofits to enhance the functionality and to improve/upgrade the associated building services Initiating a retrofit involves evaluation of the use of the building by the occupants and redesigning building elements which might offer an opportunity to maximize space efficiency, reduce energy consumption and lower the operation costs of the building. This paper elaborates on the development of a framework for a process of retrofitting the existing requirements and the associated existing services for an institutional building to enhance the functionality of the built environment.
\end{abstract}

Keywords- Functionality, Conversion, Adaptation, Reuse, Refurbishment

\section{INTRODUCTION}

The term "retrofitting functionality" refers to the functional enhancement of the existing building in accordance with the following:

- Change in usage of the space which was intended at the time of its inception/planning.

- Addition (especially vertical) of extra floors to the existing structure and augmentation of the associated functions.

- Statutory approval required for retrofitting functionality of the existing building. (FAR, height, safety/security concerns of the adjacent buildings)

- Logistic challenges including the site constraints (location, size and operational), timings of construction

Prior to initiating/making a major investment (what may amount to) in the retrofit of existing buildings for functional enhancements, upgradations, and improvements, it is imperative to evaluate whether the investment is worthwhile in view of other building conditions (WBDG, 2018).

Functionality retrofitting cannot be fully addressed without an understanding of the interconnections and interactions between its technical purposes and as well as the influences of the development impact on its environment and the associated services. There are essential stages regarding the problem of knowledge management in building renovation context in order to develop a new support framework which needs to be performed through a consensus-based process (Alyami \& Rezgui, 2012)
There can be two means through which an existing facility of a building can be improved/upgraded i.e. evaluation and demolition. This study will be focused on the process of evaluation of retrofitting the functionality pertaining to space and associated existing services in an economic manner. The functionality enhanced through retrofitting also leads to improvement in the safety aspects of the building.

The framework is created through the literature as well as case study which acts as instrumental in providing guidance for carrying out the functional enhancement and is modified as per the conditions observed in the case study undertaken to suit special requirements of the institutional typology of building. The developed framework can be considered as robust enough to be used for this particular type of building.

\section{RESEARCH OBJECTIVES}

This study aims at developing a framework for a process of retrofitting the existing requirements and the associated existing services for an institutional building to enhance the functionality of the built environment. To achieve this aim, the following are the research objectives:

1. To identify the gap between the current functions and future requirements of a building based on its occupancy, typology, location, current codes/standards and bye-laws and present the comparative assessment of space and service requirements.

2. To prepare the costing of the proposed space and service upgrade

3. To develop a framework for functionality enhancement/requirement (for buildings of similar typology).

\section{LITERATURE STUDY}

In order to ensure that the decision-making framework reflects the best practice of retrofitting, assessment methods and literature were reviewed. The inputs from numerous published works have served a sound platform for this study. This section of the study presents the summary and inferences from the various relevant literature. 


\section{A. Adapting Buildings for Changing Uses :}

Adaptation and renovation of outdated offices can prove to be a successful real estate strategy (Remøy et al, 2010). There are several reasons/risks involved:

- uncertainty about financial feasibility,

- little knowledge about the opportunities

- building conversions.

The findings show that various legal, financial, technical, functional and architectonic issues define the opportunities and risks of building conversions.

\section{B. Functional / Operational :}

The major source of the literature under this section is Whole Building Design Guide (WBDG), a program of the National Institute of Building Sciences, 2016. According to WBDG (2016), the project itself is derived from a requirement, purpose and expected result and the project is considered successful if the psychological and cultural needs of the users along with functional requirements are efficiently catered to. There are three overarching principles associated with ensuring functional building design and operations:

- Account for Functional and Psychological Needs

- Ensure Appropriate Product / Systems Integration

- Meet Performance Objectives.

In addition to the above three principles, the building functional and operational goals are most successfully met within the constraints of a project budget, therefore the relationship of function/operation and cost is an important aspect.

\section{Adaptation of an existing building over new build :}

There are three main forms of adaptation i.e. conversion, extension, and refurbishment (Watson, 2008).

In addition to the three listed above, several other terms under the general umbrella of adaptation are alteration, conservation, modernization, and maintenance. Following stages can be identified for taking a suitable decision

\section{- $\quad$ Defining the problem}

- $\quad$ Setting objectives

- Determine the options

- Evaluate options

- Selecting the option

- Deployment phase

- Control phase

\section{- Feedforward phase}

Certain issues that have to be carefully considered and evaluated in the order that the right decisions when considering adapting a building are building suitability, building structure, condition of building, aesthetics, project brief, legal issues and change of use.

\section{Change of use of refurbishment :}

The major aspects necessary for adapting the building for a change in use is the demand for and supply of buildings (Kincaid, 2003). Where a building has been vacant or underutilized for a considerable period of time, six basic options are available: market, leave vacant, refurbish, modify use, change the class of use, demolish. The key areas for decision while considering the need of change in use in any project are:

- $\quad$ secure financial resources

- retain individuals and organizations with design and construction skills

market the adapted building

- obtain approvals to the change of use and the detailed design

- $\quad$ satisfy the current and future needs of occupiers.

\section{CASE STUDY}

The case study selected for this study is an Institutional building in New Delhi. This building was completed in 1960.

Building details are as following:

Number of floors : : G+5

$\begin{array}{ll}\text { Height } & : 19.4 \text { (terrace level) } \\ \text { Occupancy Type } & : \text { Office } \\ \text { Plot Area } & : 2150 \mathrm{sqm} \\ \text { Built-up Area } & : 3450 \mathrm{sqm} \\ \text { Occupancy Type } & : \text { Office } \\ \text { Permissible FAR } & : 200\end{array}$

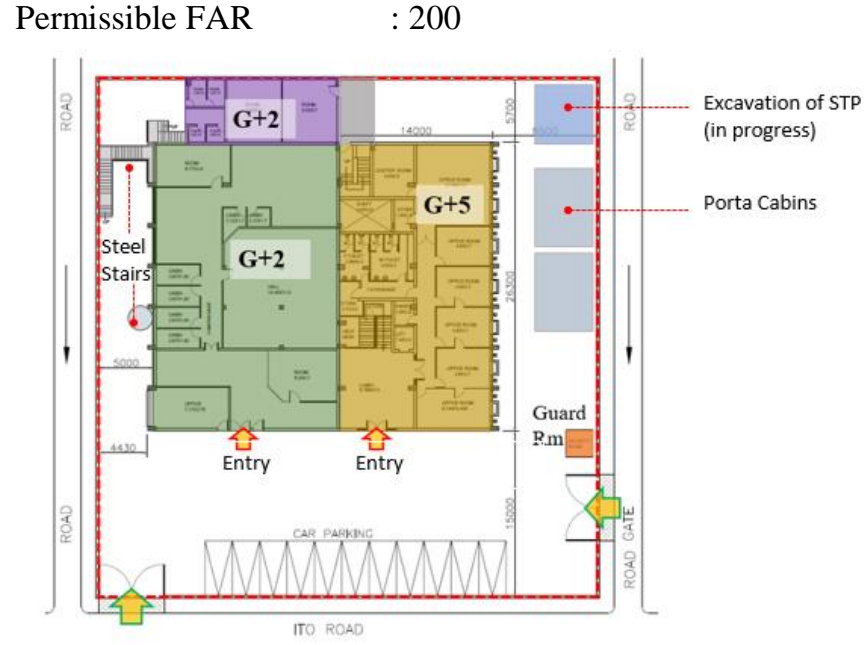

Building Plan (NITS)

Figure 1: Layout Plan of the case study

The broad methodology/steps to achieve the desired outcomes (as derived from the literature) pertaining to the case study

- Site Visit - Visual Inspection (status of services especially drainage lines, bye-laws violation, if any)

- Measurement verification of the building and site

- Developing/amending the drawings (including the Grid Plan) as per physical verification and measurements.

- Identifying the existing plumbing/drainage services (including the manholes and its connection with the municipal drains) and marking the same on the layout.

- Obtaining the number of occupants and the current utilization of the spaces (via client meetings)

- Collection of relevant data like site investigation reports, NDTs (Non-Destructive Tests), if available with the client/owner 
Based on the above steps the overall study process of the case study (Institutional building in New Delhi) is broadly divided into four categories

- Checklist to identify the existing status of the building

- Obtaining Owner's Requirements

- Observations during Site Visit

- Identifying the key barriers/challenges encountered during the retrofitting process.

1) Checklist to identify the existing status of the building
a) Current Occupancy
b) Existing space usage
c) Applicable codes / Byelaws
d) Sanitary Fixtures (WCs/ urinals)
e) Drawings (checked as per site and changed accordingly)
f) Parking numbers
g) Setback as per codes
h) Status of Rain Water Harvesting pits
i) Fire norms (tender movement/accessibility)

2) Owner' requirement
a) Replace of Soil /waste pipe stack
b) Provision of STP
c) Provision of RWH pits
d) Change in size of window openings
e) Provision of lift
f) Boundary wall (repair / rebuilt)

3) Observations During Site Visits (case study specific)
a) Soil pipes are corroded (as seen in the shaft)
b) Leakage through soil pipes
c) Portacabin in the side setback
d) Steel staircases in the side setback
e) Excavation for STP (on hold)
f) All Manholes are choked
g) Mismatch with the drawings

4) Key Barriers / Challenges (case study specific)

a) Construction has to happen in the phased manner

b) The present location of already laid services

c) Augmentation of the services with the requirements

d) Current operations / administrative works should run smoothly

e) Hight Water table $(1.5 \mathrm{~m})$ is a major barrier for excavation for STP

f) Work timings for the execution of works will be limited due to the location of the site.
g) Available height in Case of functional enhancement of the space.

\section{DEVELOPMENT OF FRAMEWORK FOR ENHANCING THE FUNCTIONALITY}

Based on the previous section, a framework for understanding the needs of the user has been formulated. The framework is created based on the literature, majorly from the 'Whole Building Design Guideline' with the recommendations and desired outcome. This framework has been modified/adapted as per the case study undertaken to suit the special requirements of an institutional typology of building.

The methodology for achieving the desired outcomes as per the recommendations are

1) Site visits

These can further be categorized based on the purpose of site visit i.e. both cross-validation of detailed measured drawings provided by the consultants and for identification of marking services and subsequently drawing them out on AutoCAD. This has provided with the necessary base data for assessment of the current performance and state of the services of the case study

2) Meetings

These include meetings with stakeholders, consultants, and users. The minutes of the meetings have been duly recorded which shall further assist in creating the required lists of stakeholders, client requirements, issues faced by consultants, issues have arisen due to existing site and building conditions et cetera

3) Other project-related documents

These include contract documents for various consultants, site investigation reports, reports pertaining to structural analysis.

4) Relevant Indian Codes and Mandatory Guidelines:

These documents shall be instrumental in providing with the required performance parameters and help in quantifying user requirements and other associated services.

The framework as per the case study undertaken to suit special requirements of the institutional typology of the building is divided into four parts majorly based on Whole Building Design Guide (2016) which are as under:

- Framework for Account for Functional and Psychological Needs

- Framework for Ensuring Appropriate Product / Systems Integration

- Framework for Meet Performance Objectives.

- Framework for function/operation and cost

\begin{tabular}{|l|l|l|l|}
\hline \multicolumn{3}{|c|}{ A - FRAMEWORK FOR ACCOUNTING FOR FUNCTIONAL NEEDS } \\
\hline S. No. & Recommendations & Expected outcome & Inputs from the Case Study \\
\hline $\mathbf{1}$ & Owner's design objectives & $\begin{array}{l}\text { List of the owner's requirements. For example, in this case, the } \\
\text { immediate requirements were to replace of Soil /waste pipe } \\
\text { stack and water risers, provision of STP, repair / rebuilt of the } \\
\text { boundary wall }\end{array}$ \\
\hline $\mathbf{2}$ & $\begin{array}{l}\text { Determination of uses and } \\
\text { different facilities to be } \\
\text { provided }\end{array}$ & Formulation of area program & Building details (Area, FAR, Height, etc) \\
\hline $\mathbf{3}$ & Consider the functional needs & Checklists of the associated services & $\begin{array}{l}\text { Listing and identification of the current status of the services. } \\
\text { For this case, it was status of soil pipes are corroded leading to } \\
\text { leakage, number of WCs/ urinals, preferred location of the }\end{array}$ \\
\hline
\end{tabular}




\begin{tabular}{|c|c|c|c|}
\hline & & & $\begin{array}{l}\text { proposed STP and provision of stormwater / external drain } \\
\text { pipe and RWH pits }\end{array}$ \\
\hline 4 & $\begin{array}{l}\text { Owner's and users' needs and } \\
\text { goals for space, quality, } \\
\text { budget, and time }\end{array}$ & Viability of Function and Cost & $\begin{array}{l}\text { This will include the consultancy cost \& execution cost } \\
\text { (including dismantling) based on the requirement }\end{array}$ \\
\hline 5 & $\begin{array}{l}\text { Reference building type } \\
\text { guidelines }\end{array}$ & List of relevant Indian codes & $\begin{array}{l}\text { For the case study, the codes referred were NBC 2016, DDA } \\
\text { Byelaws, relevant IS code for repair works, Codes for } \\
\text { plumbing and sanitary services, }\end{array}$ \\
\hline 6 & $\begin{array}{l}\text { Understand the role the site } \\
\text { plays in meeting the functional } \\
\text { needs }\end{array}$ & $\begin{array}{l}\text { Site investigation report and } \\
\text { identification of external site services }\end{array}$ & $\begin{array}{l}\text { External services were identified and marked on the drawings. } \\
\text { Also, it was proposed to have a soil investigation before the } \\
\text { excavation of STP. }\end{array}$ \\
\hline 7 & Review of provided data & $\begin{array}{l}\text { This includes meetings with } \\
\text { stakeholders, consultants, and users. }\end{array}$ & $\begin{array}{l}\text { Audit/scrutiny of the provided drawings and amendments } \\
\text { done as per site visits. }\end{array}$ \\
\hline \multicolumn{4}{|c|}{ B- FRAMEWORK FOR ENSURING APPROPRIATE SYSTEM INTEGRATION } \\
\hline S. No. & Recommendations & Expected outcome & \\
\hline 1 & $\begin{array}{l}\text { Development of design } \\
\text { concepts that meet functional } \\
\text { requirements as per area } \\
\text { program }\end{array}$ & Design proposal & $\begin{array}{l}\text { Suggested changes in the design communicated to the client } \\
\text { for perusal and there was a proposal of an extra elevator also. }\end{array}$ \\
\hline 2 & $\begin{array}{l}\text { Selection of appropriate system } \\
\text { for each application }\end{array}$ & $\begin{array}{l}\text { Unique solutions also considering } \\
\text { constructability and cost-effectiveness }\end{array}$ & $\begin{array}{l}\text { Execution proposed in a phase-wise manner so that the } \\
\text { operations of the building should be least affected. }\end{array}$ \\
\hline 3 & $\begin{array}{l}\text { Seek integrated design } \\
\text { solutions }\end{array}$ & $\begin{array}{l}\text { Design that is both functional and serves } \\
\text { user requirements }\end{array}$ & $\begin{array}{l}\text { Proposal for one new lift to cater to the current number of } \\
\text { users }\end{array}$ \\
\hline 4 & $\begin{array}{l}\text { Consider the operation and } \\
\text { maintenance of building facility }\end{array}$ & $\begin{array}{l}\text { Checklists for operation and } \\
\text { maintenance of the building }\end{array}$ & $\begin{array}{l}\text { IT was proposed to follow regular fire drills protocol, } \\
\text { maintenance of STP and monitoring IAQ }\end{array}$ \\
\hline \multicolumn{4}{|c|}{ C- FRAMEWORK FOR MEETING PERFORMANCE OBJECTIVE } \\
\hline S. No. & Recommendations & Expected outcome & \\
\hline 1 & $\begin{array}{l}\text { Assure appropriate } \\
\text { programming }\end{array}$ & $\begin{array}{l}\text { List of key stakeholders and their } \\
\text { functional requirements. Detailed } \\
\text { Minutes of meeting documenting all } \\
\text { related discussions }\end{array}$ & List of key members from client, contractor and consultants. \\
\hline 2 & $\begin{array}{l}\text { Establish design objectives and } \\
\text { their relative priority }\end{array}$ & $\begin{array}{l}\text { Listing performance goals, } \\
\text { methods/criteria of assessment of their } \\
\text { performance and their relative } \\
\text { weightage based on the building codes } \\
\text { referred to in account for functional } \\
\text { needs }\end{array}$ & $\begin{array}{l}\text { Identification of requirements as per section A of the } \\
\text { framework including the codes, building bylaws, internal and } \\
\text { external services requirements. }\end{array}$ \\
\hline 3 & $\begin{array}{l}\text { Check "lessons learned" from } \\
\text { the previous project }\end{array}$ & $\begin{array}{l}\text { Comparison of the proposed design with } \\
\text { previously collected data }\end{array}$ & $\begin{array}{l}\text { For this case study, it was learned that the soil investigation } \\
\text { should be done before excavation in areas with the high water } \\
\text { table }\end{array}$ \\
\hline 4 & $\begin{array}{l}\text { Creation of Quality Assurance } \\
\text { Programme }\end{array}$ & $\begin{array}{l}\text { Regular comparison of design with the } \\
\text { Owner's Project Requirements (OPR), } \\
\text { conducting regular meetings, keeping } \\
\text { the client updated about design } \\
\text { decisions and changes }\end{array}$ & $\begin{array}{l}\text { This includes the operation and maintenance issues like } \\
\text { maintenance of STP and monitoring IAQ }\end{array}$ \\
\hline \multicolumn{4}{|c|}{ D- RELATIONSHIP OF FUNCTION / OPERATION AND COST } \\
\hline S. No. & Recommendations & Expected outcome & \\
\hline 1 & $\begin{array}{l}\text { Establish and prioritize project } \\
\text { goals, needs, and wants early in } \\
\text { the design process }\end{array}$ & $\begin{array}{l}\text { Listing performance goals, } \\
\text { methods/criteria of assessment of their } \\
\text { performance in concurrence with the } \\
\text { owner's requirement }\end{array}$ & $\begin{array}{l}\text { This will also include the methods to achieve the client } \\
\text { requirement as mentioned in part IV of this paper. }\end{array}$ \\
\hline 2 & $\begin{array}{l}\text { Update the cost estimate } \\
\text { throughout the design process } \\
\text { and definitely at project } \\
\text { milestones }\end{array}$ & $\begin{array}{l}\text { Preparation of list of Activities and } \\
\text { associated cost }\end{array}$ & $\begin{array}{l}\text { Preparation of WBS and tentative schedule, estimation of } \\
\text { quantities and cost estimation }\end{array}$ \\
\hline 3 & $\begin{array}{l}\text { Verify the cost estimate with } \\
\text { historic project cost data and } \\
\text { industry professionals. }\end{array}$ & Comparison of estimate & $\begin{array}{l}\text { The rates were considered after getting three quotes as } \\
\text { minimum }\end{array}$ \\
\hline 4 & $\begin{array}{l}\text { Identify opportunities for } \\
\text { flexibility on bids }\end{array}$ & $\begin{array}{l}\text { Quotation from various relevant } \\
\text { vendors/agencies }\end{array}$ & $\begin{array}{l}\text { Final rates considered after obtaining Quotations from various } \\
\text { sources (market, historic, etc.) }\end{array}$ \\
\hline
\end{tabular}

VI. CONCLUSION / INFERENCES:

A detail study /appraisal regarding adaptive reuse with the functional enhancement of the built environment and analysis of the same was carried out in concurrence with the case study undertaken during this study. Following are the conclusions:
- While there are considerations are new office buildings, majority of these can be covered by the framework suggested for retrofitting through accounting for functional needs (which considers the aspect of functional requirements, flexibility in use), appropriate system integration and relationship of function and cost 
- The process of enhancing the functionality and upgrading the associated existing services for a building can boost the longer-term utility of a building

- There are also challenges and barriers to the process of retrofitting the existing requirements, which consistently concern cost; availability and price of matching existing materials may create problems; time constraints for execution (and transportation) can also be a challenge due to location of the building; execution to be done in a phased manner

- The opportunity to study during this study provided a uniquely detailed insight into how the retrofitting of the existing requirements of building to enhance its functionality and associated services is done.

- A great deal of data and several ideas have emerged during this study about how things might be done differently and possibly better in several areas.

- The tangible and intangible benefits of the retrofitting process were listed down and analyzed thoroughly at the culmination of this study.

- This was also recognized during this study that the process of enhancing the functionality and upgrading the associated existing services for a building boosts the longer-term utility of a building and hence, it's a more sustainable option than demolition and rebuilding.

- The benefits (in-tangible) for adaptive reuse identified during this study also support the views of sustainability and include:

- reducing resource consumption,

- $\quad$ extending the useful life (especially services) of buildings;

- enhancing the functionality of the built environment;

- being more cost-effective than demolition and rebuilding;

- revitalizing existing neighborhoods;

- increasing the demand for retained existing buildings;

- In addition to these benefits, there are also challenges and barriers to the process of retrofitting and adaptive reuse, which consistently concern cost. However, this is often a smokescreen complicating the real reason that it is easier under current development processes to produce a new building. The range of challenges and barriers to adopting adaptive reuse for an existing building identified during the research include:

- only being viable where the costs and benefits are factored in over the life of the building;

- older buildings may require extensive and costly refurbishment;

- can be limitations to match the performance of a new building (case-specific);

- older buildings may be unable to meet current sustainability standards (and statutory regulations also);
- availability and price of matching existing materials may create problems; and

- maintaining the structural integrity of older buildings may be difficult.

- Time constraints for execution (and transportation) can also be a challenge due to the location of the building.

- Planning to be done in a phased manner to minimize the hassle in day to day operations

- This framework can be considered as robust enough to be used for this particular type of building.

Future research: The framework developed in this study can be dealt with more parameters pertaining to other building typologies, to become robust for another kind of the buildings as well. Also, structural retrofitting can also be collaborated with the functional retrofitting to provide a single solution for addressing the issues of the retrofitting of requirements as well as the structural part of the building

\section{ACKNOWLEDGMENTS}

I am thankful to Professor (Dr.) Virendra Kumar Paul and Ar. Abhijit Rastogi for their valuable inputs and guiding me in framing the outline of this research paper.

My sincere gratitude to Prof. Dr. Chaitali Basu, for her unwavering advice, to improve the quality of this study. Her critical perspective and vast knowledge allowed me to understand the process of this research.

I would also like to extend gratefulness to Devika Nayal for extending her help to improve upon the basic frameworks pertaining to this study.

I am thankful to my classmates Sumedha Dua and Dipanshu Sharma who spared no effort in ensuring my social and academic integration throughout this study.

\section{BIBLIOGRAPHY}

[1] Alyami, S. \& Rezgui, Y., 2012. Sustainable building assessment tool development approach -Sustainable Cities.

[2] Kincaid, D., 2003. Adapting Buildings for Changing Uses Guideline for change of use refurbishment.

[3] Paradis, R., 2016. Retrofitting existing buildings- improve sustainability and energy performance.

[4] Remøy, H., Voordt, v. d. \& Theo, 2014. Adaptive reuse of office buildings into housing Opportunities and risks.

[5] Watson, P., 2008. The key issues when choosing adaptation of an existing building over new build.

[6] WBDG, 2018. Whole Building Design Guide: Functional / Operational Committee, Account For Functional Needs. 